ISLAMIC BANKING Volume 3 Nomor 1 Edisi Agustus 2017| 1

\title{
PERMASALAHAN EKONOMI SESUNGGUHNYA DALAM ISLAM
}

\author{
Fadilla \\ Sekolah Tinggi Ekonomi dan Bisnis Syariah (STEBIS) Indo Global Mandiri \\ Email: fadilla@stebisigm.ac.id
}

Abstract

\begin{abstract}
Abstrak
Inti dari masalah ekonomi yang kita pahami selama ini adalah kebutuhan manusia yang tidak terbatas sedangkan alat pemuas kebutuhan terbatas. Para ahli ekonomi konvensional menyebutnya sebagai masalah kelangkaan. Dalam Islam masalah ekonomi Islam permasalahan ekonomi adalah ditribusi yang tidak merata. Adapun tujuan dalam penelitian ini antara lain : Mengetahaui konsep permasalahan ekonomi dalam Islam, Mengetahui perbedaan permasalahan ekonomi dalam ekonomi Islam dan konvensional, dan Mengetahui cara mengatasi permasalahan ekonomi dalam Islam.

Permasalahan dalam ekonomi Islamadalah distribusi yang tidak merata sedangkan konvensional adalah kelangkaan. Solusi yang ditawarkan Islam antara lain: Masyarakat mempunyai hak khiyar. Hak khiyar adalah adalah salah satu ak bagi kedua belah pihak yang melakukan transaksi (akad) ketika terjadi beberapa persoalan dalam transaksi yang dimaksud. Hak Khiyar sendiri ada terbagi menjadi :Khiyar Tadlis (Membatalkan karanabarangnya cacat), Khiyar 'aib (kurangnya nilai tersebut dikalangan ahli pasar. Khiyar Syarat (hakpilih) yang dijadikansyarat keduanya. Masyarakat menyelesaikannya dengan media al-shulhu (perdamaian)
\end{abstract}

Kata Kunci: Masalah Ekonomi, Islam dan Konvensional

\section{Dasar Pemikiran}

Masalah ekonomi merupakan masalah yang tidak terelakan akan terjadi pada setiap individu,masyarakat, negara bahkan dunia. Masalah,negara, bahkan dunia. Masalah ekonomi yang biasanya yang dihadapi masyarakat kesejahteraab mereka berkurang. Selain itu pengangguran juga merupakan masalah ekonomi yang dihadapi negara pada umumnya sebagai akibat dari kemiskinan itu sendiri. Inti dari masalah ekonomi yang kita pahami selama ini adalah kebutuhan manusia yang tidak terbatas sedangkan alat pemuas kebutuhan terbatas. Para ahli ekonomi konvensional menyebutnya sebagai masalah kelangkaan. Kelangkaan atau kekurangan berlaku sebagai akibat dari ketidakseimbangan antara kebutuhan masyarakat dengan faktor-faktor yang tersedia dalam masyarakat. (Sukirno, 2015: 5).

Pendapat di atas berbeda dengan konsep permasalahan ekonommi yang diuangkapkan oleh para ekonomi muslim, salah satunya adalah Baqir As-Sadr. Dia 


\section{2 | Fadilla Permasalahan eKonomi SesungGuHnYA......}

berpendapat bahwa sumber daya pada hakikatnya melimpah dan tidak terbatas. Pendapat ini didasari oleh dalil yang menyatakan, bahwa alam semesta ini diciptakan oleh Allah dengan ukuran yang setepat-tepatnya. Segala susuatunya telah dikukur secara sempurna.Allah juga telah memberikan sumber daya yang cukup bagi seluruh manusia. Baqr As-Sadr juga menolak pendapat yang menyatakan bahwa keinginan manusia tidak terbatas. Ia berpendapat, bahwa manusia akan berhenti mengkonsumsi suatu barang dan jasa jika tingkat kepuasan terhadap barang dan jasa menurun atau nol. Menurut ulama ini, yang menjadi sumber uatama ekonomi adalah tidak meratanya distribusi sumber daya diantara manusia. (Rozalinda, $2016: 34$ ).

Penelitian ini membahas tentang bagaimana cara pengelolaan harta dalam Islam serta bagaiamana pemerataan sumber daya yang diatur dalam Islam. Konsep permasalahan ekonomi yang diangkat dalam Islam yang berbeda dengan konsep permaslahan yang diangkat dalam ekonomi konvensional, begiitu juga dengan solusi yang ditawarkan. Banyak pemikir-pemikir ekonomi yang menuangkan gagasannya dalam pembangunan ekonomi Islam, penelitian ini mengangkat dan pembahas hal tersebut. Oleh sebab itu judul penelitian ini adalah Permasalah Ekonomi Sesungguhnya Dalam Islam.

\section{Rumusan Masalah :}

Berdasarkan latar belakang di atas maka peneliti akan mengungkapkan beberapa masalah yang akan dibahas dalam penelitian ini antara lain :

1. Bagaimana konsep permasalahan ekonomi dalam Islam?

2. Apa perbedaan permasalahan ekonomi dalam ekonomi Islam dan konvensional?

3. Bagaiamana cara mengatasi permasalahan ekonomi dalam Islam?

\section{Tujuan Penelitian}

Adapun tujuan dalam penelitian ini antara lain :

1. Mengetahaui konsep permasalahan ekonomi dalam Islam

2. Mengetahui perbedaan permasalahan ekonomi dalam ekonomi Islam dan konvensional

3. Mengetahui cara mengatasi permasalahan ekonomi dalam Islam 
ISLAMIC BANKING Volume 3 Nomor 1 Edisi Agustus 2017 | 3

\section{Manfaat Penelitian :}

Ada beberapa manfaat penelitian, penelitian ini juga begitu. Manfaat itu meliputi praktis dan akademis.

Praktis :

1. Agar para umat Islam dapat mengetahui sesungguhnya bagaimana permasalahan ekonomi dalam Islam, serta penyelesaiannya dalam Islam

2. Agar umat Islam dapat menghindari permasalahan tersebut

\section{Akademisi :}

1. Penelitian ini berguna bagi para peneliti selanjutnya yang akan meneliti tentang permsalahan ekonomi dalam Islam

2. Peneliti ini berguna bagi sumber refernsi bagi mahasiswa atau orang lain yang akan menulis ataumengkaji tentang ekonomi Islam

\section{Landasan Teori}

1. Ekonomi Islam dan Konvensional

Dawam Raharjo memahamiistilah ekonomi Islam kedalam tiga kemungkinan pemaknaan pertama yang dimaksud ekonomi Islamadalah ilmu ekonomi yang berdasarkan nilai atau atau ajaran Islam. Edua yang dimaksud ekonomi Islam adalah sistem.sistemyang menyagkit pengaturab yaitu pengaturan kegiatan ekonomidalamsuatu masyarakat atau negara berdasarkan suatu cara atau metode tertentu. Adapun pilihan ketiga adalah ekonomi Islam dalam perekonoman umat Islam ( Rianto dan Amalia, $2014: 7)$

Dari beberapa definisi dan pengertian ekonomi Islam yang telah dikemukakan oleh pakar ekonomi Muhamad Syauqi al-Fabjari menrumuskan pengertia ekonomi Islam dengan rumusan yang sederhana. Ekonomi Islamadalah aktivitas ekonomi yang diatur sesuai dengan dasar-dasar dan prinsip-prinsip Islam. (Rozalinda, $2016: 13$ )

Dalam ilmu ekonomi konvensional ilmu ekonomi merupakan suatu studi mengenai individu-individu dan masyarakat membuat pilihan, dengan atau tanpa penggunaan uang, dengan menggunakan sumber daya yang terbatas tetapi dapat digunakan dalam berbagai cara untuk menghasilkan berbagai jenis barang dan jasa dan 
4 | Fadilla Permasalahan ekonomi sesungguhnya......

menstribusikannya untuk kebutuhan konsumsi sekarang dan dimasa yangakan datang, kepada berbagai kepentingan indivisu dan golongan (Sukirno, 2015 :9)

\section{Metodologi Penelitian}

Penelitian ini merupakan penelitian yang kualitatif lebih tepatnya library research, dengan menggunakan sumber referensi dari buku-buku dan jurnal yang telah ada.

\section{Pembahasan}

\section{Permasalaha Ekonomi dalan Konsep Islam dan Konvensional}

Inti dari masalah ekonomi yang kita pahami selama ini adalah kebutuhan manusia yang tidak terbatas sedangkan alat pemuas kebutuhan terbatas. Para ahli ekonomi konvensional menyebutnya sebagai masalah kelangkaan. Kelangkaan atau kekurangan berlaku sebagai akibat dari ketidakseimbangan antara kebutuhan masyarakat dengan faktor-faktor yang tersedia dalam masyarakat. Disuatu pihal dalam masyarakat selalu terdapat keinginan yang relatif tidak terbatas untuk menikmati berbagai jenis barang dan jasa yang dapat memenuhi kebutuhan mereka. oleh sebab itu masyarakat tidak dapat memperoleh dan menikmati semua barang yang mereka butuhkan atau inginkan. Mereka harus membuat membuat pilihan. (Sukirno, 2015 :5)

\section{Kebutuhan Masyarakat}

Yang dimaksudkan dengan kebutuhan masyarakat adalah keinginan masyarakat untuk memperolehbarang dan jasa Keinginan untuk memperoleh barang dan jasa dapat dibedakan kepada dua bentuk :

a) Keinginan yang disertai oleh kemampuan untuk membeli

b) Keinginan yang tidak disertai oleh kemampuan untuk membeli.

Barang yang dibutuhkan manusia terdiri dari benda yang dapat dilihat dan diraba secara fisik seperti baju, sepatu, makanan dan minuman. Jasa bukanlah berbentuk benda sebab ia merupakan layanan seorang atau suatu barang yang akan memenuhi kebutuhan masyarakat(Sukirno, 2015: 5). Banyak pemikir ekonom muslim yang membahas tentang permasalahan ekonomi dalam Islam diantaranya adalahBaqr As-sadr dan Alghazali. 
ISLAMIC BANKING Volume 3 Nomor 1 Edisi Agustus 2017 | 5

\section{Pemikiran Ekonomi Baqr As-Sad}

Imam al-Sayid al-Stahid Muhamad Baqir bin Al-Sayyid Hairar IbnIsmail al-Sadr lahir di Kazhimiyyah, pinggiran Kora Baghdad, Irak pada tanggal 01 Maret 1935 (Aravik, 2017 : 13 ). Muhamad Baqir al-Sadr marupakan pemikir muslimyang produktif dalammenghasilkan karya diberbagai bidang disiplin ilmu. Walaupun tidak memiliki latar belakang pendidikan ekonomi, akan tetapi Baqir al-sadr piawai dalammenjelaskan pemikiran teori-teori ekonomi konvensional. Kitab Iqtishduna telah terbukti sebagai salah satu studi komparatif yang laing tajam dalamsistemekonomi Islam, kapitalis dan sosialis Marxisme,dan dikutip oleh hampir semua ekonomi modern. (Aravik, 2017 : 15)

Menurur umala ini masalah ekonomi muncul karna adanya distribusi yang tidak merata dan adil sebagai akibat sistemekonomi yang membolehkan eksploitasi pihak yang kuat terhadap pihak yang lemah. Yang kuat memiliki akses terhadap sumber daya sehingga menjadi sangat kaya sementara yang lemah menjadi sangat miskin karena tidak memiliki sumber daya. (Aravik, $2017: 18$ ).

Menurut Al-Sadr sitribusi sumber-sumber produksiyang menjadi dasar, mendahulu proses produksi itu sendiri. Jadi, dalam perspektif nya yang pertam adalah sumber produksi kemudian produksi. Dari sini dapat dipahami bahawa yang menjadi titik awal atau tingkatan pertamasistemekonomi, bukan produksi sebagaimana dalam ekonomi politik tradisional. Dalam sistem ekonomi Islamdistribusi sumber produksi mendahulu proses produksi otomatis berada pada tingkatan kedua(Aravik, 2017 : 18).

Teori distribusi secara Islami menurut ulama ini terbagi menjadi 2 (dua) bentuk yaitu :

a) Pekerja yang melakukan kerja pada kekayaan alammenjadi pemilik hasil kerjanya, yakni peluang

b) Usaha untuk memanfatkan atau mengambil keuntungan dari kekayaan dari kekayaan alam apa pun membuat sin pelaku usaha ememperolej hal dari kekayaan alam tersebut.

\section{Teori danTanggung jawab Negara Menurut Baqr Al-Sadr}

Pemikiran Baqr al- Sadr tanggung jawab negara dalam bidang ekonomi tidak bisa dipisahkan dengan pemikiran beliau tentang negara Islam. Teori tanggug jawab negara 
6 | Fadilla PeRmasalahan eKonomi SesungGuhnya......

yang dikembangkan olehal-Sadr dalam buku Iqtishaduna, berisi doktrin ekonomi Islam.Dalam teori tanggung jawab negara al-Sadr menyatakan bahwa hukum Islammenugaskan negara untuk menjamin kebutuhan seluruh individu (Aravik, 2017 : 21).

Teori ini membahas tiga konsep dasar :

1. Konsep jaminan sosial

2. Keseimbangan sosial

3. Teori intervensi negara

Dari berbagai keterangan di atas dapat dipahami bahwa pemikiran Baqr A-sadr tentang awal munculnya persoalan ekonomi merupakan pemikiran yang orisinal dan justru tidak disepakati oleh sebagian besar ekonomi muslim lain, akan tetapi pemikiran ini diamini oleh beberapa teori yan berasaldari pemikiran ekonomi konvensional, sepertimarinal unility, law of dimishing return, dan hukum Gosen. Disamping itu,pada kondisi sekaran tidak ada lagi negara yang menrapkan sisitem kapitalis, begitu juga kepemilikan pribagi mulai diakui negara komunis, halini menunjukkanbahwasebagian pemikiran ekonomiBaqr al-Sadr, terutama tentang peran dan tanggung jawab pemerintah dibidang ekonomi.

Cara-cara bekerja sistem ekonomi dipengaruhi oleh sifat pemilikan yang berlaku. Dalam sistem ekonomi kapitalisme, individu barhak memiliki sesuatu, baik alat produksi maupun alat konsumsi. Bahkan hak milik seseorang dilindungi hukum. Dan pemerintah berkewajiban melindungi hak milik ini.

Setiap negara mengetahui hak kebebasan individu untuk memiliki harta perorangan. Setiap individu dapat memiliki, membeli, dan menjual hartanya menurut yang dikehendaki tanpa hambatan. Individu mempunyai kuasa penuh terhadap hartanya dan bebas menggunakan sumer-sumber ekonomi menurut cara yang dikehendaki. Setiap individu berhak menikmati manfaat yang diperoleh dari produksi dan distribusi serta bebas untuk melakukan pekerjaan.

Dalam sistem ekonomi sosialisme, negaralah menjadi pemilik utama. Faktor-faktor produksi, terutama yang penting, dikuasai negara. Hak milik perorangan praktis terbatas sekali pada barang-barang yang tidak terlalu penting. Kalaupun ada hak milik di luar negara, maka yang dimungkinkan adalah hak milik masyarakat. (Syafiq, 2004 :169) 
ISLAMIC BANKING Volume 3 Nomor 1 Edisi Agustus 2017 |7

\section{Pemikiran Ekonomi Al-Ghazali}

Hujatul Islam Abu Hamid Muhammad bin Muahad Al-Tusi Al-Ghazali lahit di Tus, sebuah kota kecildi khurasan, Iran, pada tahun 450 H (1058). Sejak muda, Alghazali hidup dalam dunia Tasawuf Al-ghazali juga sangat antusias dengan ilmu pengetahuan. Seperti halnya paracendikiawan muslimterdahulu perhatian Al-Ghazali terhadap kehidupan masyarakat tidak terfokus pada satu bidang tertentu, tetapi meliputi seluruh aspek kehidupan manusia.

Pemikiran sosio ekonomi Al-Ghazali berfokus pada perilaku individu berakar dari sebuah konsep yang disebut dengan "Fungsi kesejahteraan sosial Islami". Menurut Alghazali, kesejahteraan (maslahah) dari suatu masyarakat tergantung pada pencarian dan pemeliharaan lima tujuan dasar yakni agama(al-dien), hidup atau jiwa (nafs), keluarga atau keturunan (nasl) harta atau kekayaan (mal) intelek atau akal (Aql). Ia menitikberatkan bahwa sesuai tuntunan wahyu, tujuan utama kehidupan umat manusia adalah untuk mencapai kebaikan kehidupan dunia dan akhirat. (Karim, 2006 :318)

\section{Solusi Islam dalam Ketidakadilan Eknonomi}

Padadasarknya Islam telah memberikan solusi terhadap ketidakadilan dalam praktik ekonomi. Solusi tersebut antara lain:

a. Penegak hukum yang khusus memonitor segala bentuk pelanggaran hak yang dilakukan pelaku usaha( Aravik, 2016: 83-84).

b. Hal ini sejalan dengan pemikiran Syarfi. (2004) Berbagai satuan ekonomi, pelaku ekonomi dan kelembagaan Masyarakat mempunyai hak khiyar. Hak khiyar adalah adalah salah satu ak bagi kedua belah pihak yang melakukan transaksi (akad) ketika terjadi beberapa persoalan dalam transaksi yang dimaksud. Hak Khiyar sendiri ada terbagi menjadi :

1) Khiyar Tadlis (Membatalkan karanabarangnya cacat)

2) Khiyar 'aib (kurangnya nilai tersebut dikalangan ahli pasar

3) Khiyar Syarat ( hakpilih) yang dijadikansyarat keduanya.

c. Masyarakat menyelesaikannya dengan media al-shulhu (perdamaian)

Masyarakat menyelesaikannyadengan jawatan al-hsibah (lembaga pengawasan ini bekerja dalam satu hubungan pengaruh mempengaruhi antara satu dengan yang lainnya 
8 | Fadilla PeRmasalahan eKonomi SESUngGuHNyA......

sehingga berfungsi secara konsisten. Yang penting adalah bahwa sistem ini mampu menanggapi gangguan luar dan dapat menyesuaikan diri dengan kondisi yang berobahobah. Suatu sistem ekonomi harus mampu bertahan menghadapi berbagai gangguan perobahan. Selama ini telah lahir bermacam-macam sistem ekonomi, namun banyak pula kemudian tenggelam dilanda arus perubahan.

Di antara sistem ekonomi yang masih berpengaruh adalah sistem ekonomi pasar (kapitalisme) dan sistem ekonomi komando (sosialisme). Pertumbuhan ekonomi dunia banyak dirangsang oleh pertarungan antara dua sistem ini. Gagalnya kedua sistem ini dalam menciptakan kesejahteraan masyarakat, mengharuskan adanya pemecahan. Karena itu, umat manusia sangat membutuhkan suatu sistem yang lebih baik yang mampu memberikan semua elemen berperan dalam rangka mencapai kesejahteraan dan kebahagian umat manusia sejati. Sistem ekonomi Islam tampil sebagai solusi, bukan opsi, yang banyak mendapat perhatian dunia.

Sistem ekonomi yang mampu hidup terus sesungguhnya telah mengalami penyesuaian dengan perobahan lingkungan, dan tidak lagi murni sepenuhnya sesuai dengan sistemnya semula. Tetapi kerangka pokok dari sistem ekonomi tetap membedakan diri dengan sistem-sistem ekonomi lain.

Ciri-ciri pokok perbedaan sistem ekonomi satu dengan lain tercermin minimal dalam empat hal :

1. Cara proses pembangunan itu berlangsung;

2. Sifat pemilikan (ownership) yang berlaku;

3. Pembagian hasil-hasil pembangunan;

4. Sistem rangsangan dan motivasi. Dari keempat ciri-ciri pokok inilah ditinjau perbedaan sistem ekonomi Islam dengan sistem-sistem ekonomi lainnya, jika sistem ekonomi Islam dilaksanakan dengan sebenarnya halbisa menjadi soklusi dalam permasalahan ekonomi. (Syarfi, 2004 : 168). 
ISLAMIC BANKING Volume 3 Nomor 1 Edisi Agustus $2017 \mid 9$

\section{Simpulan}

Berdasarkan pembahasan di atas dapat dimbil beberapa kesimpulan

1. Permasalahan dalam ekonomi Islam adalah distribusi yang tidak merata sedangkan konvensional adalah kelangkaan.

2. Solusi yang ditawarkan Islam antara lain:

a. Masyarakat mempunyai hak khiyar. Hak khiyar adalah adalah salah satu ak bagi kedua belah pihak yang melakukan transaksi (akad) ketika terjadi beberapa persoalan dalam transaksi yang dimaksud. Hak Khiyar sendiri ada terbagi menjadi : Khiyar Tadlis (Membatalkan karanabarangnya cacat), Khiyar 'aib (kurangnya nilai tersebut dikalangan ahli pasar, Khiyar Syarat ( hakpilih) yang dijadikansyarat keduanya.

b. Masyarakat menyelesaikannya dengan media al-shulhu (perdamaian)

c. Masyarakat menyelesaikannyadengan jawatan al-hsibah (lembaga pengawasan 
10 | Fadilla Permasalahan ekonomi sesungguhnya......

\section{DAFTAR PUSTAKA}

Aravik, Havis, 2016. "Penyelesaian Sengketa Konsumen Melalui Jalur Al-Shulhuh dan Jawatan al-Hisbah", Economica Sharia, Volume 2 Nomor 1 Edisi Februari 2016.

Aravik, Havis. 2016. Ekonomi Islam Konsep,Teori dan Aplikasi serta Pandangan Pemikir Ekonomi Islam dari Abu Ubaid Samapi Al-Maududi. Empat Dua : Malang

Aravik, Havis. 2017. Sejarah Pemikiran Ekonomi Islam Kontemporer. Kencana : Jakarta.

Karim, Adiwarman Azwar,2006. Sejarah Pemikiran Ekonomi Islam. PT Raja Grafindo Persada : Jakarta

Rianton, Nur Al Arif dan Euis Amalia ,2010. Teori Mikro Ekonomi Suatu Perbandingan Ekonomi Islam dan Ekonomi Konvensional. Kencana : Jakarta

Rozalinda, 2016. Ekonomi Islam Teori dan Aplikasinya pada Aktivitas Ekonomi. PT Raja Grafindo Persada : Jakarta

Sukirno, Sadono, 2015. Mikro Ekonomi Toeri Pengantar. PT Raja Grafindo Persada : Jakarta

Syarfi, Muhamad.2004. Sistem Ekonomi Islam ditengah Pertarungan Sistem Ekonomi Konvensional. Forum Padagogik. 